\title{
Use of condensed water from air conditioning systems
}

https://doi.org/10.1515/eng-2018-0031

Received January 14, 2018; accepted June 7, 2018

\begin{abstract}
Facing the growing demand for water, discussions on environmental sustainability and conservation of this resource have become increasingly important. Among the possibilities for water conservation, air conditioning systems have potential applicability because, during their operation, water is generated via the condensation of air humidity, which is normally discarded. Thus, the objective of this work was to evaluate the water released by air conditioning equipment (condensed water) installed in the Laboratory of Water Analysis (LAnA) qualitatively and quantitatively, in order to verify its potential for use in the laboratory itself. For this, the quality of the water produced by three air conditioners was compared water quality parameters found in the literature, as well as with water produced by a distiller and an ultra-purifier, both used in the LAnA. Water quality was evaluated using physicochemical parameters (i.e. pH, electrical conductivity, resistivity, alkalinity, turbidity, apparent color and hardness) and microbiological parameters (i.e. total coliforms, Escherichia coli and heterotrophic bacteria). The average water flow produced by the three monitored air conditioners was 3.08 L/hour, which is higher than the daily consumption by the LAnA, indicating that its use would be quantitatively propitious. The physicochemical and microbiological analyses found that, condensed water can be used in the routine activities of LAnA. However, for its use as reagent-grade water, a prior treatment would be necessary, mainly due to the presence of heterotrophic bacteria.
\end{abstract}

Keywords: reagent-grade water; air conditioning; water use; laboratory

\footnotetext{
^Corresponding Author: Paulo Sergio Scalize: Universidade Federal de Goiás Goiânia, GO Brazil, E-mail: pscalize.ufg@gmail.com Samara Silva Soares, Andreia Cristina Fonseca Alves: Doctor student, Universidade Federal de Goiás

Thaynara Azevedo Marques, Gabriel Gade Martins Mesquita: Graduation, Universidade Federal de Goiás
}

\section{Introduction}

The expansion of urbanization, coupled with reduction of available quality water resources, has led to concerns regarding environmental sustainability, which have resulted in formal discussions on the subject such as those at the Stockholm Conference in 1972, ECO 92, Rio +10 and Rio +20 , among others. After these debates, the concept of reuse and utilization became widely diffused, showing the potential in our environment for optimization of resources, such as the case of water generated by air conditioning systems or as referred to in this research, condensed water [13].

Details on studies related to condensate's potential use, in terms of quantity and quality are available in literature. [2] analyzed the reuse of condensed air conditioning water in a university campus, obtaining results that indicated water as a viable and safe source for direct use in campus, such as in bathrooms, laboratories, sidewalk washes and irrigation gardens. Already [4] has analyzed a system of collecting water from air conditioning of a hotel and continuous treatment of the same. The authors observed that the final water quality, permitted its use for drinking purposes in the building.

According to [5], the operation of an air conditioner is based on the withdrawal of warm air from the environment, concomitant with the introduction of cold air. The evaporator unit, which is part of this equipment, is located in the interior of the environment, and is responsible for capturing hot air, which is directed to the condensing unit, located outside of the environment. Here, the captured air will undergo the inverse process, which captures the air from the external environment, and directs it to circulate through cooling coils following the evaporator unit, which releases the cooled air to the internal environment [2]. The

\footnotetext{
Nara Ballaminut: Doctor, Faculdade União de Goyazes Antonio Carvalho João Albuquerque: Doctor, Universidade da Beira Interior
} 
process of cooling air in the coils promotes the condensation of the gaseous water present in the hot air mass, generating liquid water as a by-product [3]. Among the more specific uses of water, there is the use in laboratory activities. In this context, [6] and [7] emphasized the importance of reagent-grade water quality for the execution of several laboratory tests, as well as their monitoring, since altering water quality may lead to inaccuracies in the results of tests. Therefore, it is desirable that the condensed water to be used meet the parameters established by guiding entities, such as the Clinical and Laboratories Standards Institute (CLSI) or the American Society for Testing and Materials (ASTM).

In their review, [7] describe the CLSI Type I classification of reagent-grade water as water whose applications include ultrapure water, molecular biology assays and cell culture. Classification of Type II includes water for general use in the preparation of culture media and solutions, in biochemical assays and for microbiological cultures; while Type III, is used for washing glass-material and autoclaving. The authors also present the classification used by ASTM, which classifies reagent-grade water into four classes, according to physicochemical characteristics (Type I, Type II, Type III and Type IV), and three other classes according to the microbiological characteristics (Type A, Type B and Type C).

Considering the potential use of condensed water produced by air conditioning systems and the accentuated water consumption needed to make distilled water, the present research aims to evaluate the quality of the condensed water generated during the operation of air conditioners and its possible application in the activities developed in the laboratory itself.

\section{Material and methods}

This study took place in the Laboratory of Water Analysis of the School of Civil and Environmental Engineering, Federal University of Goiás (LAnA / EECA / UFG), Goiânia, Goiás, Brazil. The capitation and collection system consisted of three air condensing units, one of 9000 BTUs (brand MIDEA) and the other two of 12000 BTUs and 24000 BTUs (brand ELGIN), all connected by $25-\mathrm{mm}$ diameter PVC pipe with connections and accessories ensuring insulation from the external environment, thereby preventing possible contamination (Figure 1a). During the study period, air conditioners operated at temperatures between 20 to $24^{\circ} \mathrm{C}$, where the annual mean temperature in the city was $26.57^{\circ} \mathrm{C}$ and relative air humidity was $55.95 \%$. The system converged to a single point of condensed water release, where collections were made, and the accumulated volume stored in a 100-L closed reservoir (Figure 1b). This reservoir contained a system to prevent overflow and a tap for volumetric collection. Initially, the entire system line was cleaned by sanitization with $1.0 \mathrm{~N}$ hydrochloric acid solution, followed by three successive flushes with ultrapure water.

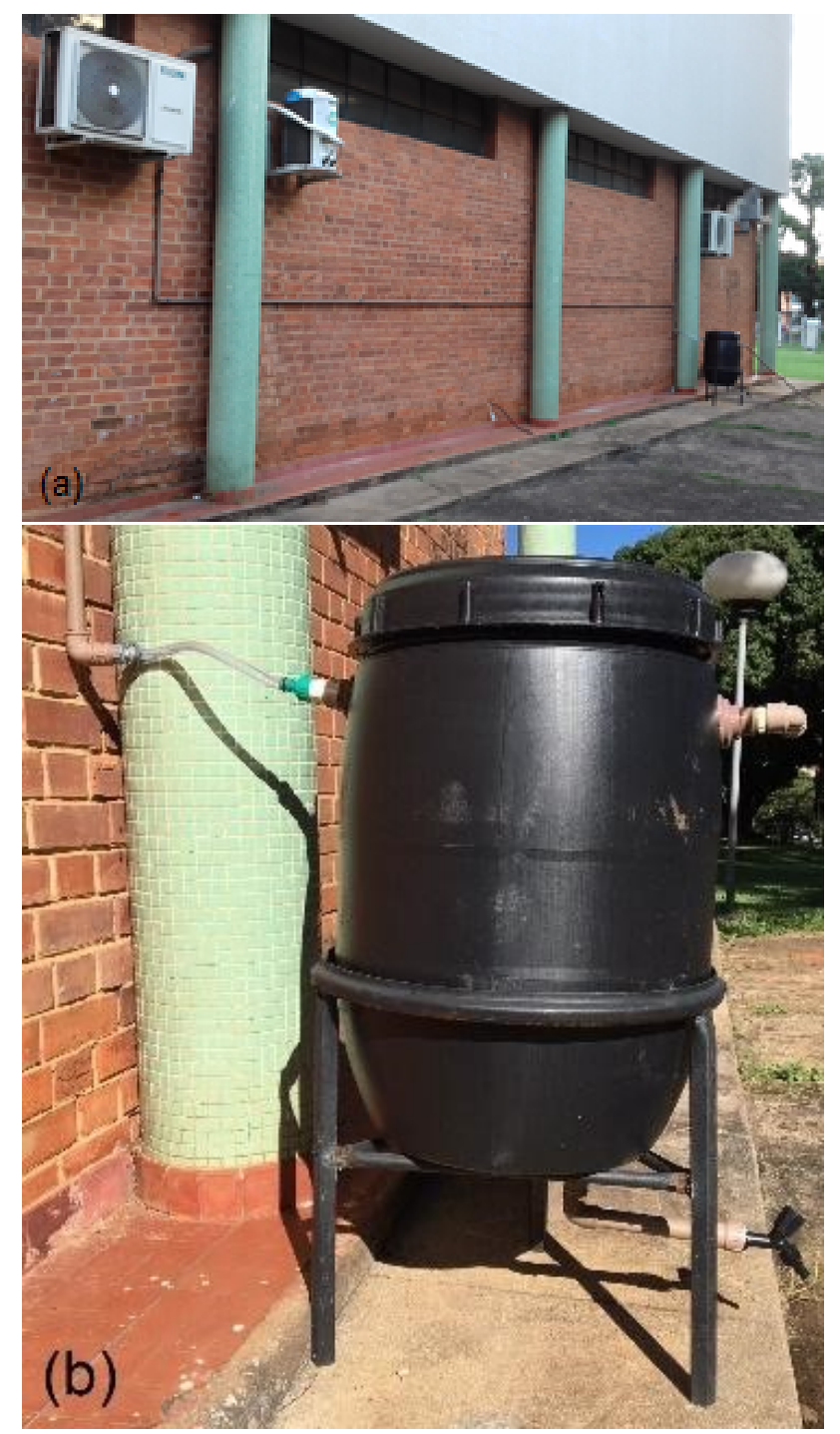

Figure 1: The water storage and collection system located outside the Laboratory of Water Analysis of the Federal University of Goiás (a), as well as the detail of the reservoir for the storage of collected water (b).

For purposes of comparison, distilled water from a distiller (FANEM, 724/2-A), and ultrapure water from an ultrapurifier (GEHAKA, Master All), were collected directly from the outlet pipe and evaluated. 
Quantitative analysis took place on a single day, with the samples being collected between 9 AM and 6 PM. Qualitative analyses included physicochemical and microbiological parameters and followed the requirements of the procedures established in standard methods [8], as described in Table 1. Sampling water from the distiller, ultrapurifier and the air conditioning unit took six days, with five days of daily collection in the morning. On the fifth day of sampling, hourly collections were made for six consecutive hours corresponding to the operating period of the laboratory. The heterotrophic bacteria analyses were performed only during the fifth day when 5 samples were collected. Thus, 10 samples were collected for each type of water, with all analyses being performed immediately after collection.

All samples were submitted to a Principal Component Analysis (PCA), for interpretation of the results obtained from the samples collected from the air conditioning units, distiller, and ultra-purifier.

\section{Results and Discussion}

The air conditioner units produced a mean flow rate of $3.08 \mathrm{~L} / \mathrm{h}$, ranging from 2.7 to $4.1 \mathrm{~L} / \mathrm{h}$ (Figure 2), which represents $30.8 \mathrm{~L}$ of water produced from $8 \mathrm{AM}$ to $6 \mathrm{PM}$ daily. These values are close to those found by [9], who observed a total flow rate of $4.25 \mathrm{~L} / \mathrm{h}$ at the Technology Center of UFRN-Brazil, with $1.06 \mathrm{~L} / \mathrm{h}$ for a $12000 \mathrm{BTU}$ unit, $1.04 \mathrm{~L} / \mathrm{h}$ for a 9000 BTU unit and $2.25 \mathrm{~L} / \mathrm{h}$ for a 24000 BTU unit. However, [10] observed a flow rate of $0.50 \mathrm{~L} / \mathrm{h}$ for a 12000 BTU device and $0.38 \mathrm{~L} / \mathrm{h}$ for a 9000 BTU device; but, did not quantify that for a 24000 BTU device. Values well below that are quantified in the present study. According to [2], the flow produced by air conditioners can be variable and depends on the power of the equipment and found that, for air conditioners from 9000 BTUs up to 24000 BTUs, the relationship with air volume is linear. In addition, [2] pointed out that other factors may interfere with the production of water from the equipment, such as temperature and relative humidity of the local air and equipment model and maintenance. The present study found that the volume of condensed water produced is sufficient to meet the demands of the laboratory in question, which consumes a volume of less than 20 liters of water daily.

Qualitatively, the bacteriological analysis showed absence of Escherichia coli and total coliforms in the three water samples analyzed, as well as the absence of heterotrophic bacteria in ultrapure water. However, heterotrophic bacteria were detected in the distilled and con-

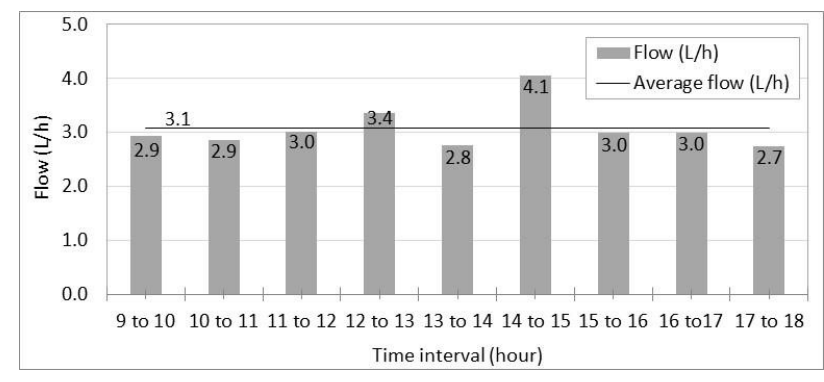

Figure 2: Volume of condensed water produced during the operation of the air condenser LAnA/UFG.

densed waters, particularly in greater quantities in the latter (Figure 3).

Based on the CLSI standardization, which differentiates water quality among three types, and the ASTM standardization, which characterizes water among three types, the review by [7], stated that the average value of heterotrophic bacteria in condensed water is over that recommended for all microbiological categories of water according to the ASTM. However, for the CLSI, considering the maximum amount of CFU found, condensed water fell within the limits defined for types II and III. The authors also report that, according to CLSI, the use of clinical reagent-grade water (CLRW) should have a maximum bacterial count of $10 \mathrm{CFU} / \mathrm{mL}$. When special-grade reagent water (SRW) is required, for example in the case of DNA and RNA testing, the review recommends that, laboratories should specify the reagent grade water for their use according to the needs of the analyses.

In this way, to increase the possibility of using condensed water, it would need to be treated to reduce or minimize the count of heterotrophic bacteria. According to Standard Methods [8], some processes are considered excellent for reducing bacteria, including distillation, filtration and ultrafiltration. Thus, it is suggested that a filtration treatment be applied to condensed water intended to be used as reagent grade water.

The presence of bacteria of the genus Legionella has not been evaluated here. However, comment on its importance should be made, since it is a genus of interest in public health and may lead to errors in the analyzes carried out in laboratories. [11] evaluated a contamination of cooling towers of air conditioning systems by $L e$ gionella, in Shanghai, to identify that $58.9 \%$ had Legionella presence. The Legionella species identified in the study were predominantly the Legionella pneumophila. The authors also demonstrated that, in point out of air temperatures (between $25-35^{\circ} \mathrm{C}$ ) represent an ideal variation for the growth of this bacteria genus which is necessary in your monitoring. The same species was already iden- 
Table 1: Physicochemical and microbiological parameters analyzed, as well as the analytical techniques used according to Standard Methods [8].

\begin{tabular}{|c|c|c|c|}
\hline Parameter & Unit & Analytical technique & Method \\
\hline Alkalinity & $\mathrm{mg} \mathrm{CaCO} / 3 / \mathrm{L}$ & Titulometric Method & $2320 \mathrm{~B}$ \\
\hline $\mathrm{pH}$ & - & Electrodemaster & $4500-H+B$ \\
\hline Turbidity & Nefelometric Turbidity Unit (NTU) & Nephelometric & $2130 \mathrm{~B}$ \\
\hline Apparent color & Hazen Unit (HU) & Spectrophotometric & $2120 B$ \\
\hline Electric conductivity & $\mu \mathrm{S} / \mathrm{cm}$ at $25^{\circ} \mathrm{C}$ & Potentiometric & $2510 B$ \\
\hline Hardness & $\mathrm{mg} \mathrm{CaCO} / \mathrm{L}$ & Titulometric Method EDTA & $2340 \mathrm{C}$ \\
\hline Resistivity & $\mathrm{M} \Omega \cdot \mathrm{cm}$ at $25^{\circ} \mathrm{C}$ & Potentiometric & $2510 B$ \\
\hline Total coliforms & Mesenteric Lymph Nodes (MLN)/100 mL & Chromogenic Substrate & $9223 \mathrm{~B}$ \\
\hline Escherichia coli & Mesenteric Lymph Nodes (MLN)/100 mL & Chromogenic Substrate & $9223 \mathrm{~B}$ \\
\hline Heterotrophic bacteria & Colony Forming Unit (CFU)/mL & Pour Plate & $9215 \mathrm{~B}$ \\
\hline
\end{tabular}

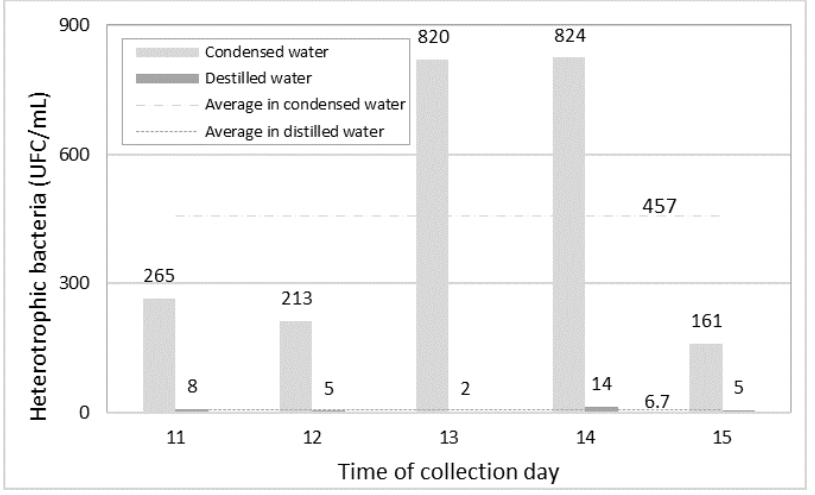

Figure 3: Quantity of heterotrophic bacteria in CFU/ml found in distilled and condensed water throughout the monitoring period.

tified in Kuwait region using a water-cooling tower system. In this case, $c a$. $84 \%$ of the samples analysed presented the mentioned bacteria with counts ranging from 1 to $88 \mathrm{CFU} / \mathrm{mL}$ [12]. The legionella species was also found in condensed water in Brazil (São Paulo state). In this study, ca of 9.7\% of Legionella with concentrations ranging from $1,0 \times 10^{2}-1,6 \times 10^{2} \mathrm{UFC} / \mathrm{mL}$ was identified. A specific genus, Legionella pneumophila, was found in condensed water obtained from hospital [13].

The $\mathrm{pH}$ range of the condensed water samples varied from 6.6 to 7.4 (Figure 4), corroborating other studies, such as [14] which observed a range of 7.0 to 7.3 and [2] which documented a range from 6.7 to 7.8. Distilled water had a $\mathrm{pH}$ range of 6.8 to 7.2 and ultrapure water between 5.1 and 6.0. It is important to point out that when the water passes through a purification process, its temperature is higher immediately after its exit than that found in stored water. Thus, when it is exposed to the atmosphere, it is subject to the dissolution of ionic impurities into its composition, such as $\mathrm{CO}_{2}$, which can change values of the analyzed parameters [17].
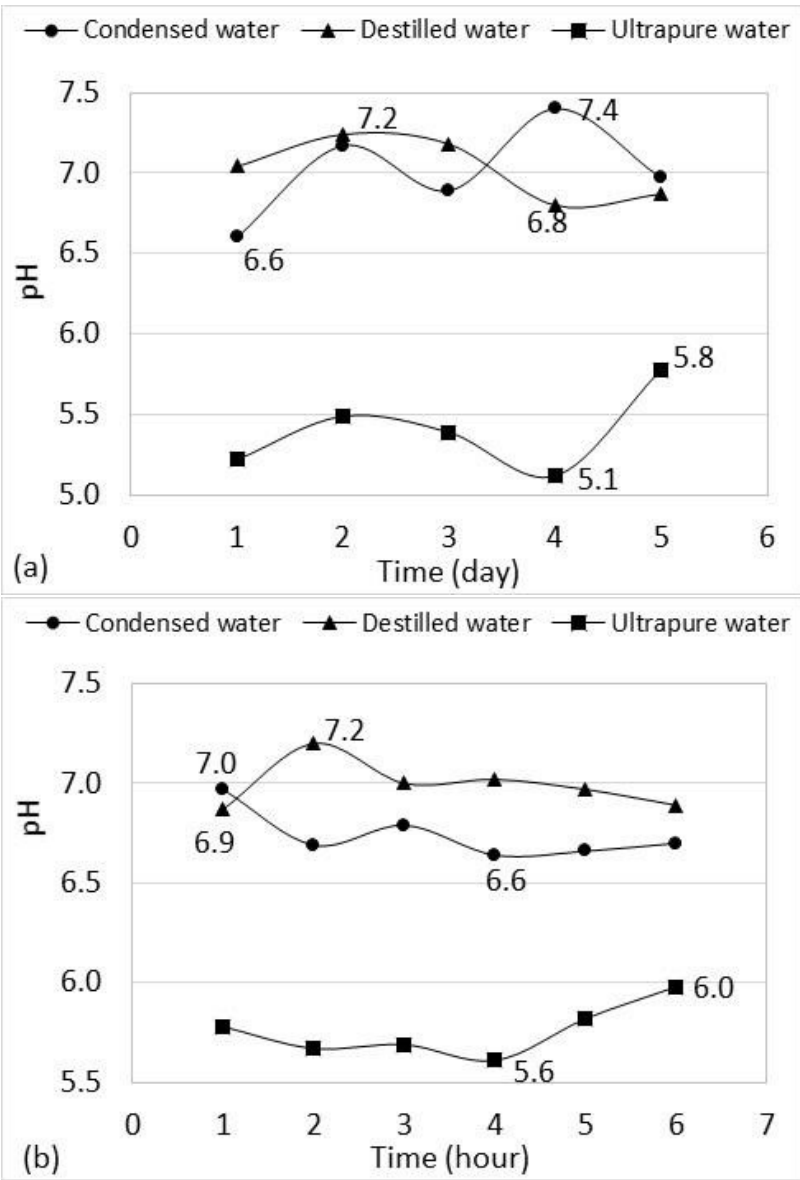

Figure 4: $\mathrm{pH}$ values found in condensed, distilled and ultrapure water, with daily (a) and hourly (b) monitoring.

The average turbidity of the samples was lower than 0.40 NTU for all three water types, with the lowest values 
being found for ultrapure water, followed by condensed water. The average turbidity observed in condensed water was lower than that presented by [15], which was 2.01 NTU for research conducted in Saudi Arabia. On the other hand, [16], observed a turbidity of 0.45 NTU for condensed water in a study carried out in the state of Paraíba, Brazil, corroborating the data observed here.

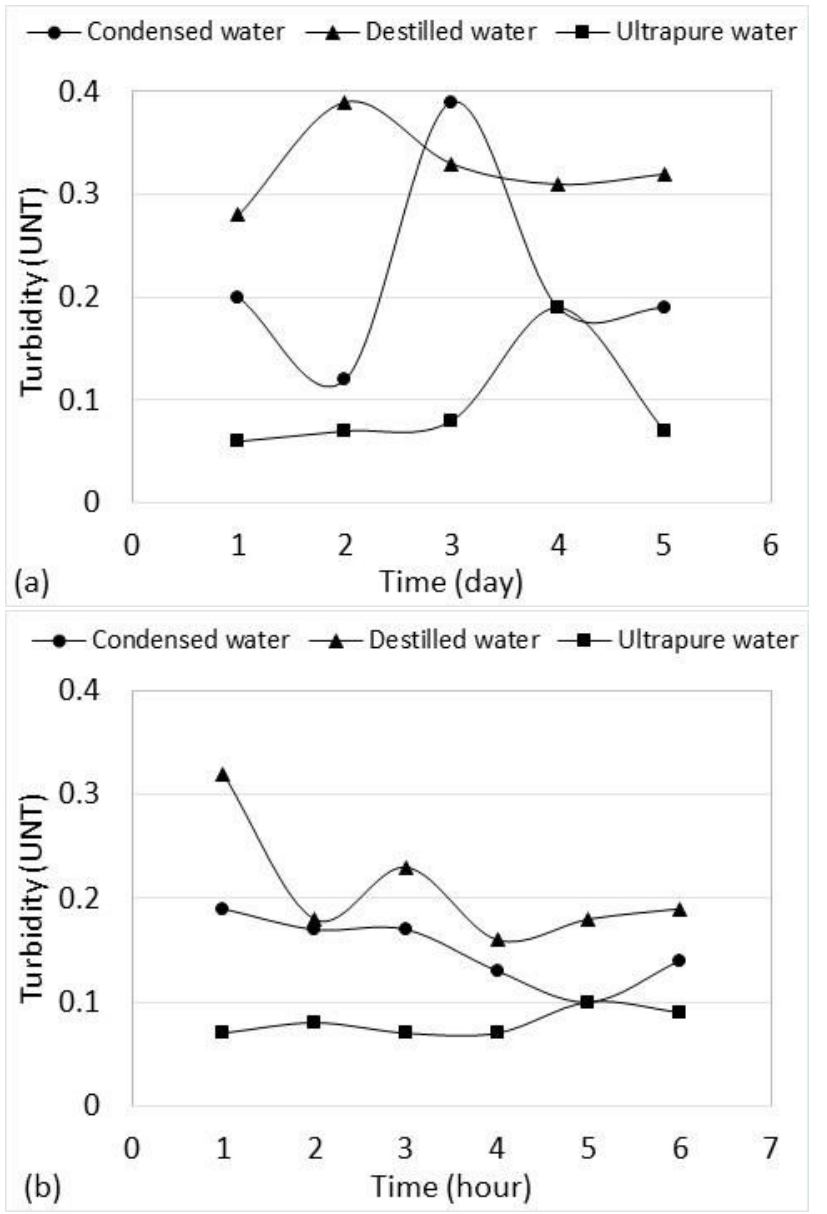

Figure 5: Turbidity values found in condensed, distilled and ultrapure waters, with daily (a) and hourly (b) monitoring.

As shown in Figure 6a (daily monitoring) and 6b (hourly monitoring), the lowest mean alkalinity value was obtained for ultrapure water with $0.24 \mathrm{mg} \mathrm{CaCO}_{3} / \mathrm{L}$ $(\mathrm{SD}=0.07)$, followed by condensed water with 0.78 $\mathrm{mg} \mathrm{CaCO}_{3} / \mathrm{L}(\mathrm{SD}=0.29)$ and distilled water with 2.0 $\mathrm{mg} \mathrm{CaCO}_{3} / \mathrm{L}(\mathrm{SD}=0.25)$. The alkalinity obtained in the samples of condensed water ranged from 0.4 to $1.3 \mathrm{mg}$ $\mathrm{CaCO}_{3} / \mathrm{L}$, corroborating those observed by other authors, as is the case of [14] and [16], who observed, respectively, alkalinity of $1.08 \mathrm{mg} \mathrm{CaCO}_{3} / \mathrm{L}$ and $0.47 \mathrm{mg} \mathrm{CaCO} / \mathrm{L}$.

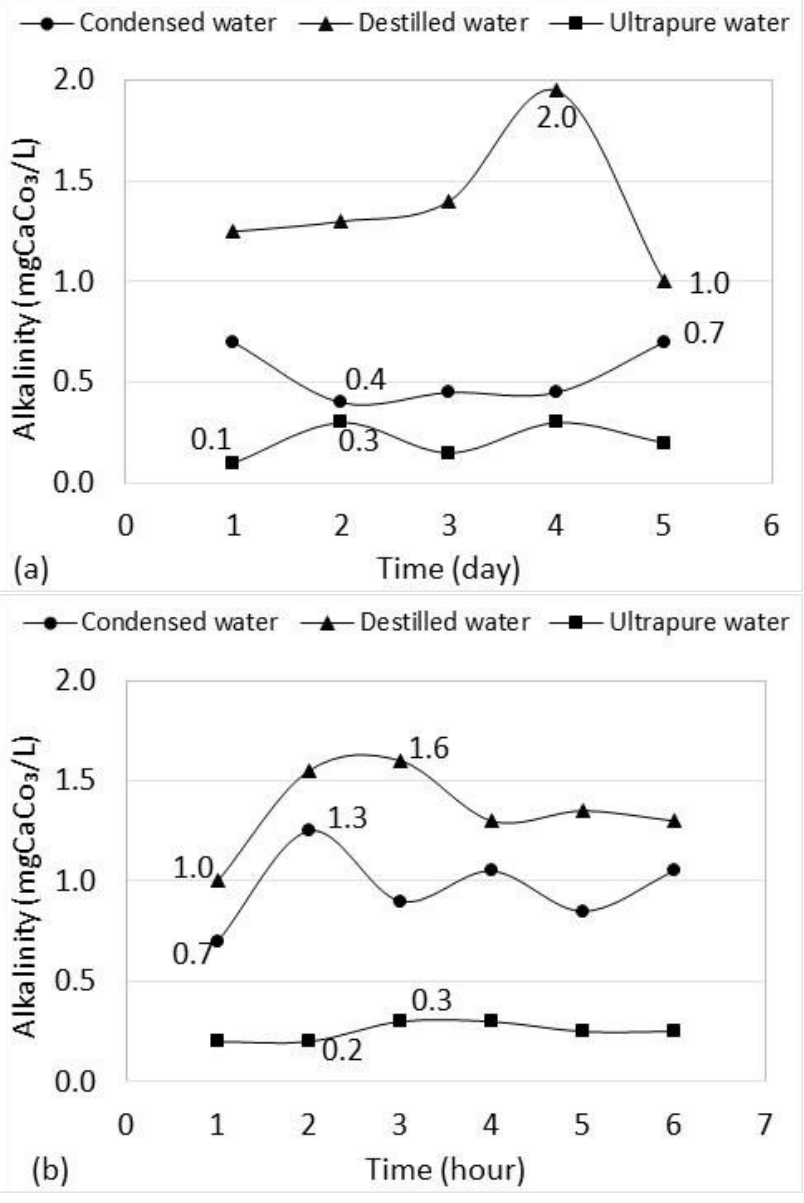

Figure 6: Alkalinity values found in condensed, distilled and ultrapure water, with daily (a) and hourly (b) monitoring.

The average resistivity of condensed water was around $0.053 \mathrm{M} \Omega \cdot \mathrm{cm}(\mathrm{SD}=0.013)$, distilled water was $0.021 \mathrm{M} \Omega \cdot \mathrm{cm}$ $(\mathrm{SD}=0.002)$ and ultrapure water was $0.577 \mathrm{M} \Omega \cdot \mathrm{cm}$ $(\mathrm{SD}=0.101)$. Thus, the resistivity of condensed water was closer that of distilled water (Figure 7a and $7 b$ ).

According to Standard Methods [8], reagent-grade water is classified as high quality when the resistivity is higher than $10.0 \mathrm{M} \Omega \cdot \mathrm{cm}$, medium quality when the resistivity is higher than $1.0 \mathrm{M} \Omega \cdot \mathrm{cm}$ (but lower than $10.0 \mathrm{M} \Omega \cdot \mathrm{cm}$ ) and low quality when the resistivity is higher than $0.1 \mathrm{M} \Omega \cdot \mathrm{cm}$ (but lower than $1.0 \mathrm{M} \Omega \cdot \mathrm{cm}$ ). Accordingly, all three types of water of the present study are considered to be of low quality. Furthermore, condensed water does not meet the established standards for clinical reagentgrade water (CLRW), when comparing the mean results with standards established by CLSI and the ASTM, as outlined in the review by [7].

The low water quality, according to the parameter of resistivity, could be explained by the fact that water is subject to the effect of dissolved $\mathrm{CO}_{2}$, which will produce 
$\mathrm{CO}_{3}{ }^{2-}, \mathrm{HCO}_{3}{ }^{-}$and $\mathrm{H}^{+}$ions that reduce water resistivity. The resistivity of pure water, at $25^{\circ} \mathrm{C}$, is approximately $18.2 \mathrm{M} \Omega \cdot \mathrm{cm}$, and when exposed to the atmosphere, rapidly approaches $1.0 \mathrm{M} \Omega \cdot \mathrm{cm}$. In addition, accurate resistivity measurements are not feasible when measuring cells exposed to the atmosphere because of the ionic contamination described above. Therefore, immersion cells cannot be recommended for measurements of high purity water resistivity [17].
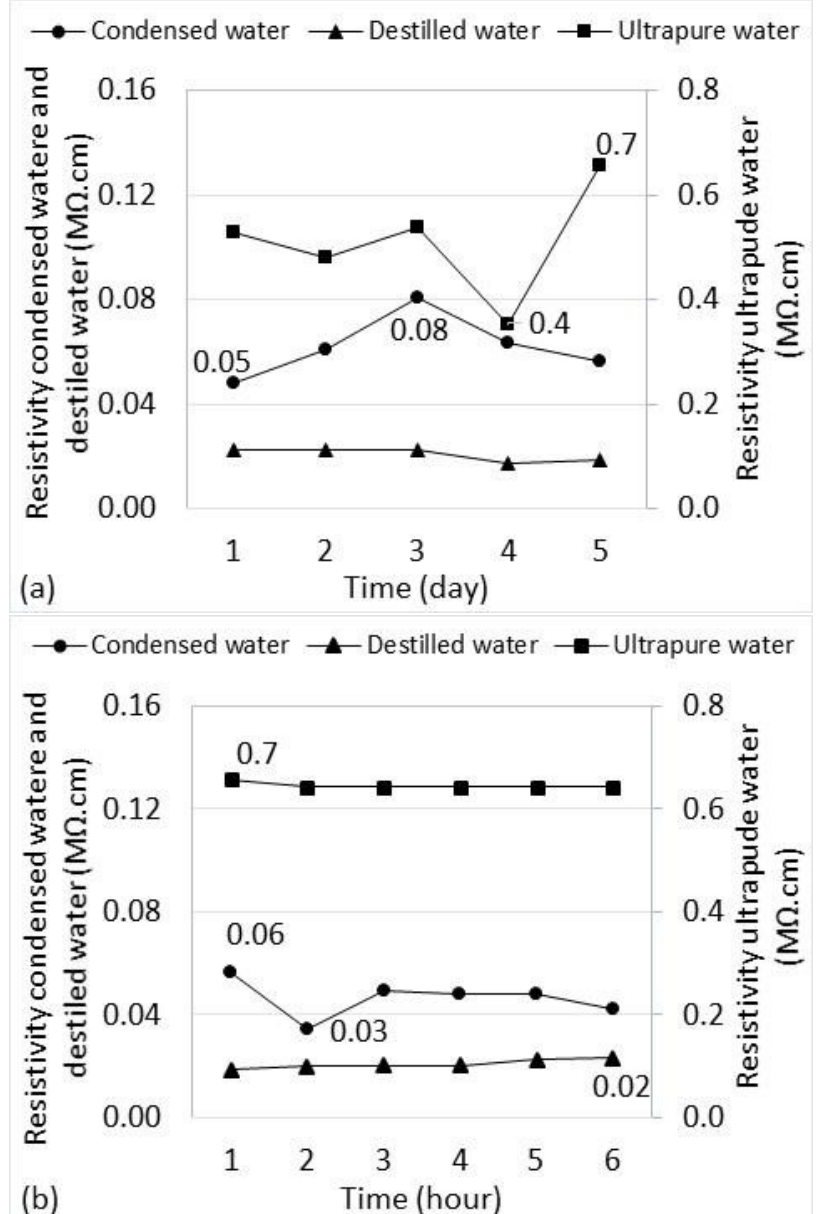

Figure 7: Resistivity values found in condensed, distilled and ultrapure water, with daily (a) and hourly (b) monitoring.

The obtained values of electrical conductivity (EC) showed an average of $48.11 \mu \mathrm{S} / \mathrm{cm}(\mathrm{SD}=4.95)$ for distilled water, $1.76 \mu \mathrm{S} / \mathrm{cm}(\mathrm{SD}=0.50)$ for ultrapure water and 19.23 $\mu \mathrm{S} / \mathrm{cm}(\mathrm{SD}=4.96)$ for condensed water. The latter being practically the same as that obtained by [14], who observed an EC of $20.76 \mu \mathrm{S} / \mathrm{cm}$ in their qualitative-quantitative study of condensed water. Figure 8 shows the daily (Figure 8a) and hourly (Figure $8 \mathrm{~b}$ ) values for conductivity. The variation for condensed water was 12.02 to $28.78 \mu \mathrm{S} / \mathrm{cm}$. [2] ob- served similar values of between 10.13 and $20.69 \mu \mathrm{S} / \mathrm{cm}$, but, higher values than those found in the present study have been reported, such as that of [16], who observed an $\mathrm{EC}$ of $70 \mu \mathrm{S} / \mathrm{cm}$ in condensed water.

The values observed in the present study were higher than the levels established in the Standard Methods [8], which may be the result of inaccuracies due to the influence of other variables in the measuring equipment.
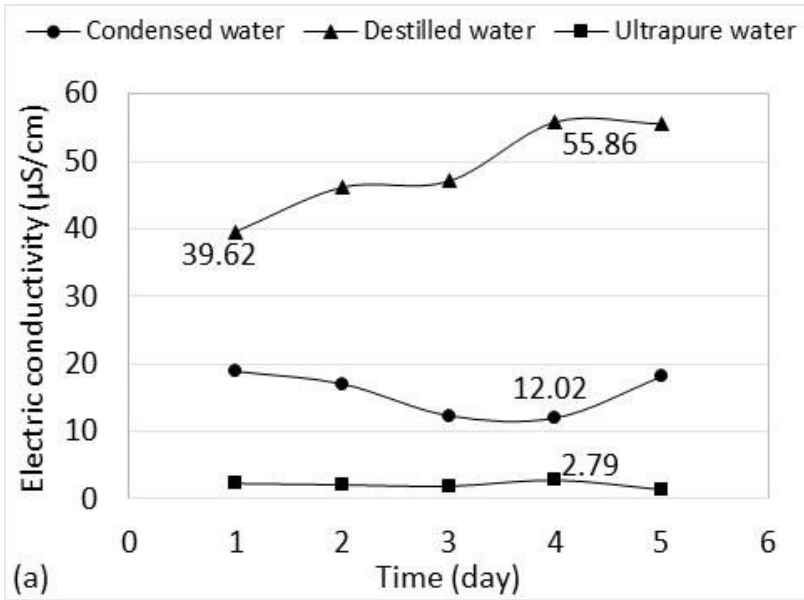

$\rightarrow-$ Condensed water $\longrightarrow$ Destilled water $\rightarrow$ - Ultrapure water

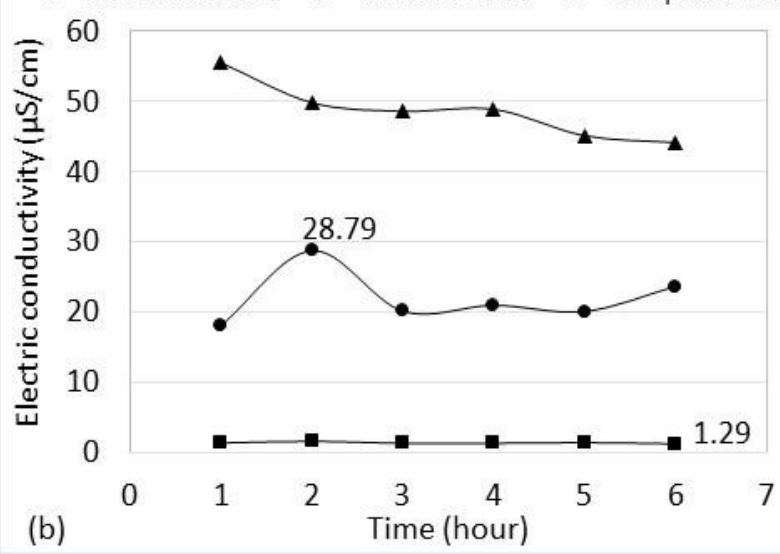

Figure 8: Electrical conductivity values found in condensed, distilled and ultrapure waters, with daily (a) and hourly (b) monitoring.

According to [18], apparent color refers to suspended particles, which is not recommended for reagent-grade water since, the medium under analysis can interact with the particles present and may alter the results of tests performed in the laboratory.

Regarding the results of apparent color, with the exception of distilled water, the values found were lower than $0.8 \mathrm{HU}$, with mean values of $0.37 \mathrm{HU}(\mathrm{SD}=0.21), 0.54$ $\mathrm{HU}(\mathrm{SD}=0.21)$ and $1.10 \mathrm{HU}(\mathrm{SD}=0.99)$ for condensed, ultrapure and distilled water, respectively. The values found for condensed water were lower than those observed by [16], 
who reported 4.0 HU $( \pm 0.001)$. In general, the results were below $2.7 \mathrm{HU}$ for all waters.

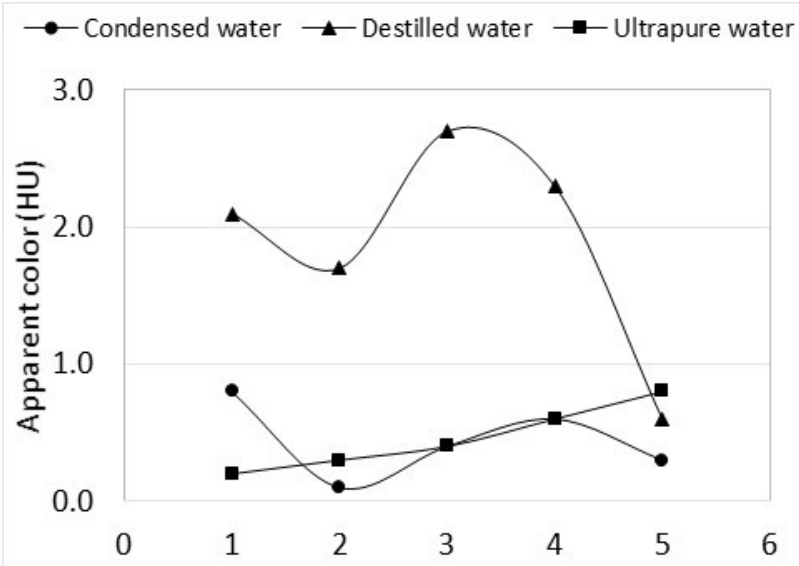

(a)

$\multimap$ Condensed water $\rightarrow$-Destilled water $\rightarrow$ - Ultrapure water

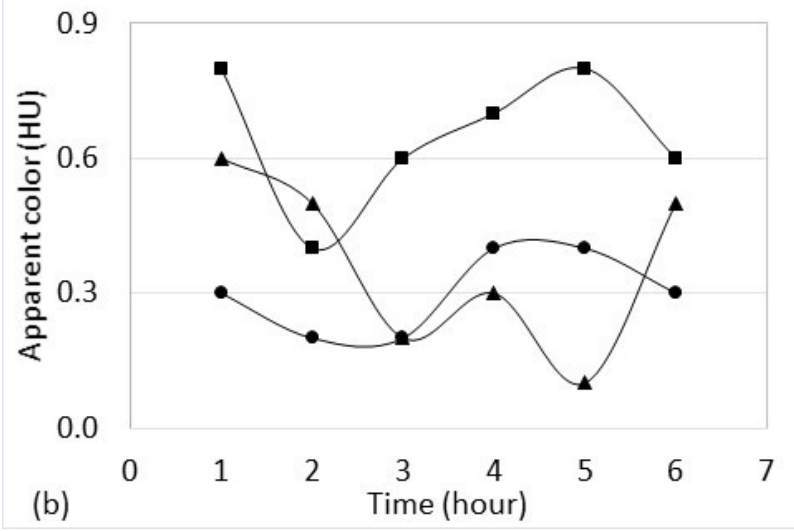

Figure 9: Apparent color values found in condensed, distilled and ultrapure water, with daily (a) and hourly (b) monitoring.

The average daily hardness of condensed water was $3.60 \mathrm{mg} \mathrm{CaCO}_{3} / \mathrm{L}(\mathrm{SD}=1.78)$, while those of distilled it was $28.4 \mathrm{mg} \mathrm{CaCO}_{3} / \mathrm{L}(\mathrm{SD}=12.91)$, and ultrapure water was $3.10 \mathrm{mg} \mathrm{CaCO}_{3} / \mathrm{L}(\mathrm{SD}=1.73)$. These values are lower than the average values observed by [14], $9.30 \mathrm{mg} / \mathrm{L}$, [2], $4.65 \mathrm{mg} / \mathrm{L}$ and [16], $12.0 \mathrm{mg} / \mathrm{L}(\mathrm{SD}=0.001$ ).

Condensed water possessed values of hardness practically equal to that of ultrapure water (Figure 9a and 9b), ranging from 2.0 to $6.0 \mathrm{mg} \mathrm{CaCO}_{3} / \mathrm{L}$ for condensed water and from 1.0 to $6.0 \mathrm{mg} \mathrm{CaCO}_{3} / \mathrm{L}$ for ultrapure.

According to [18], hardness establishes the concentration of multivalent cations present in the water. Therefore, a possible explanation for greater hardness of the distilled water than those of condensed and ultrapure water is inadequate distillation, due to the inflow of incoming water into the equipment not being regulated in accordance with the technical specifications of the apparatus, thereby making distillation ineffective, causing cations to be transferred from treated water to the distilled water.
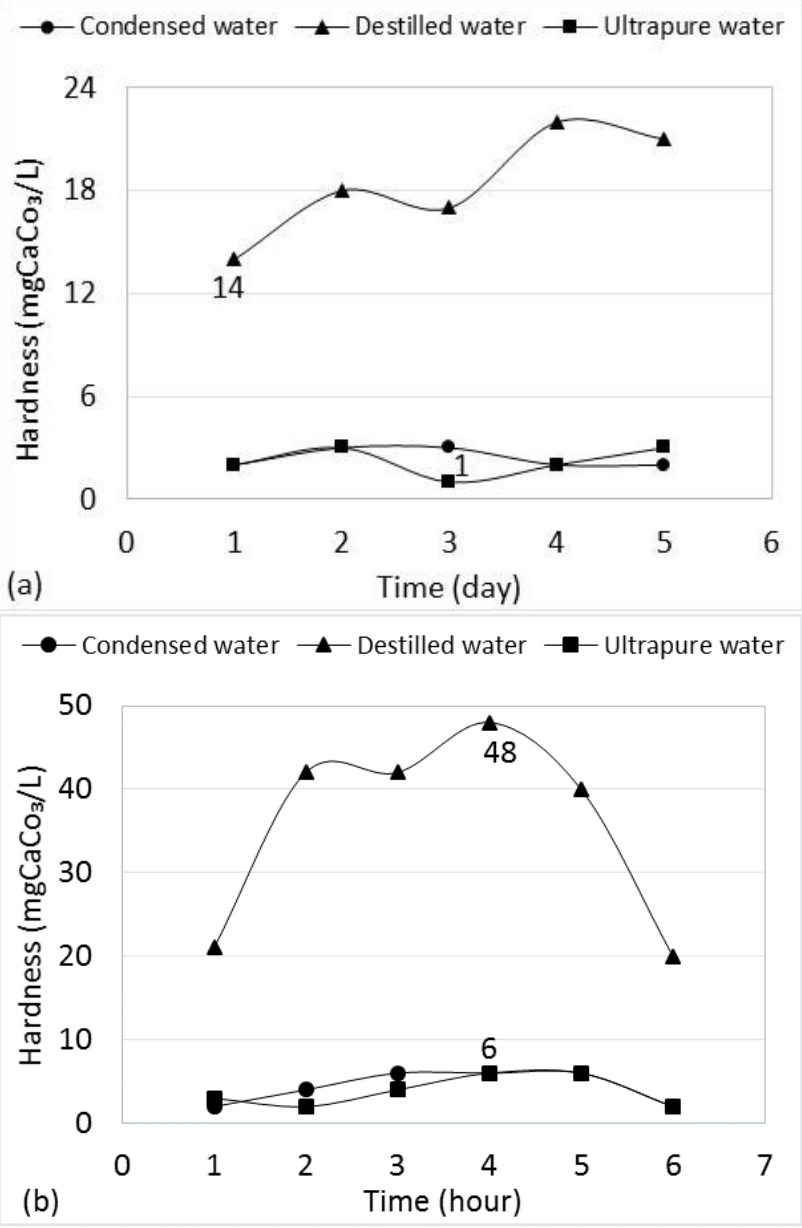

Figure 10: Hardness values found in condensed, distilled and ultrapure waters, with daily (a) and hourly (b) monitoring.

The first two axes of the principal components analysis (PCA) explained $81.7 \%$ of the total variance. Furthermore, a correlation was found between the parameters and the types of water analyzed (Figure 11), with ultrapure water and condensed water having similar characteristics. Distilled water exhibited more graphically distant values, evidencing differences in the quality since its parameters had higher values compared to the other two waters.

The loadings of the PCA are provided in table 2, which represents the weight of the variables in the linear combination with the main components, that is, the variables with greater weight are the most important from a statistical point of view. Regarding Factor 1, which explains $66.73 \%$ of the total variance of the observed data, conductivity and alkalinity are the parameters that interfere the 
most with the quality of condensed, ultrapure and distilled water.

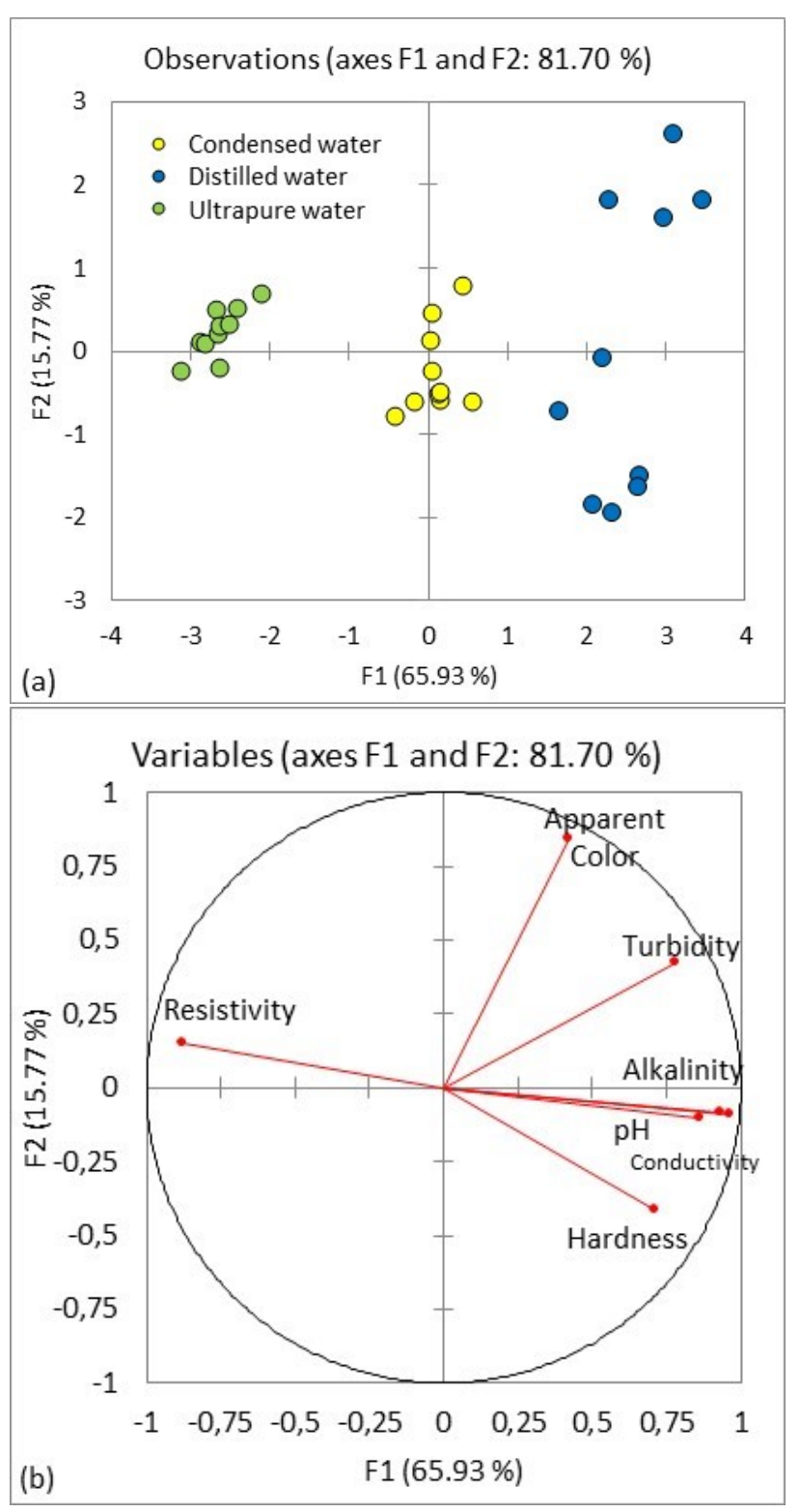

Figure 11: Principal Component Analysis to the group condensed, distilled and ultrapure water. Samples whereupon (a) set of data represented by each group and (b) orientation of the variables considered.

\section{Conclusions}

Based on the results of the physicochemical and bacteriological analysis of the present work, it can be concluded that condensed water possesses a level of quality interme-
Table 2: Loadings of the samples in relation to the direction of the main components (Factor 1 and 2) for the water types studied.

\begin{tabular}{lcc}
\hline Variable & Factor $\mathbf{1}$ & Factor 2 \\
\hline pH & 0.8647 & -0.1049 \\
Turbidity & 0.7830 & 0.4226 \\
Alkalinity & 0.9339 & -0.0845 \\
Resistivity & -0.8764 & 0.1523 \\
Conductivity & 0.9628 & -0.0913 \\
Hardness & 0.7127 & -0.4138 \\
Apparent color & 0.4231 & 0.8393 \\
\hline
\end{tabular}

diate to that of distilled water and the ultrapure water; but, being closer to the latter. Thus, condensed water has the potential to replace distilled water in the activities of the Laboratory of Water Analysis (LAnA).

The types of water tested presented low quality in relation to the parameter of resistivity and electrical conductivity, not meeting the limits for water grade reagent according to Standard Methods and for use in clinical laboratory.

In terms of bacteriological quality, the development of heterotrophic bacteria in the condensed and distilled waters was observed and depending on the intended use of the water in the laboratory, it is suggest that a treatment be done to reduce the quantity of heterotrophic bacteria in condensed water.

It can be concluded that the volume of condensed water produced daily by the air conditioner units of the present study are sufficient to meet the demands of the laboratory.

Future research related to the use of condensed water is recommended, particularly regarding the analysis of water quality parameters required by international regulatory agencies. In addition, the influence of local air quality on the quality of condensed water needs to be investigated.

\section{References}

[1] Mota, T. R., Oliveira, D. M. D., Inada, P. Reutilização da água dos aparelhos de ar condicionado em uma escola de ensino médio no município de Umuarama-PR. Proceedings of VII Encontro Internacional de Produção Científica, Paraná, Brazil, Oct 2011.

[2] Cunha, J. A. O., Ozório, C. V. de L., Pires, R. B., Almeida, J. V. de, Melo, I. E., Willian, P. Quantificação e caracterização das águas de aparelhos de ar condicionados para uma proposta de reúso direto no IFCE-Campus Quixadá. Proceedings of Encontro Intercontinental Sobre a Natureza, Ceará, Brazil, Nov 2015.

[3] Barbosa, T.; Coelho, L.: "Sustentabilidade por meio do reuso da água dos aparelhos de ar-condicionado da faculdade de tecnolo- 
gia deputado Waldyr Alceu Trigo - FATEC sertãozinho" Revista Academus, Vol. 4 nㅇ 1 (2016), pp. 1-10.

[4] Magrini, A., Cattani, L.; Cartesegna, M.; Magnani L.: “Integrated systems for air conditioning and production of drinking waterPreliminary considerations" Energy Procedia, Vol. 75 (2015), pp. 1659-1665. https://doi.org/10.1016/j.egypro.2015.07.406

[5] Rigotti, P. A. C. Projeto de aproveitamento de água condensada de sistema de condicionadores de ar. Trabalho de Conclusão de Curso. Universidade Regional do Noroeste do Estado do Rio Grande do Sul, Rio Grande do Sul, Brazil, 2014.

[6] Mendes, M. E.; Fagundes, C. C.; Porto, C. C. do; Bento, L. C.; Costa, T. G. R.; Santos, R. A. dos; Sumita, N. M.: "A importância da qualidade da água reagente no laboratório clínico" Jornal Brasileiro de Patologia de Medicina Laboratorial, Vol. 47 no 3 (2011), pp. 217-223.

[7] Nabulsi, R.; Al-Abbadi. M. A.: "Review of The Impact of Water Quality on Reliable Laboratory Testing and Correlation with Purification Techniques" Laboratory Medicine, Vol. $45 \mathrm{n} \cong 4$ (2014), pp. 159-165.

[8] APHA-AWWA-WEF. Standard Methods for examination of water and wastewater. 22th Edition. Washington, DC: American Public Health Association, USA, 2012.

[9] Pimenta, P. L. Análise quantitativa do aproveitamento da água dos aparelhos de ar condicionado do Centro de Tecnologia da UFRN. Trabalho de Conclusão de Curso. Universidade Federal do Rio Grande do Norte, Rio Grande do Norte, Brazil, 2014.

[10] Silveira, F. C. N., Pinto, R. de O., Bessa, M. J. C., Lameu, E. V. M. Análise econômica e sustentável do reúso da água dos aparelhos de ar condicionado de um hotel. Proceedings of XXVII ENANGRAD, São Paulo, Brazil, 2016.
[11] Lin, H.; Xu, B.; Chen, Y.; Wang, W.: "Legionella pollution in cooling tower water of air-conditioning systems in Shanghai, China" Journal of applied microbiology, Vol. $106 \mathrm{n} \cong 2$ (2008), pp. 606612. http://dx.doi.org/10.1111/j.1365-2672.2008.04031.x

[12] Al-Matawah, Q.; Al-Zenki, S.; Al-Azmi, A.; Al-Waalan T.; AlSalameen F.; Hejji A. B.: "Legionella detection and subgrouping in water air-conditioning cooling tower systems in Kuwait" Environmental Science and Pollution Research, Vol. $22 \mathrm{n}-13$ (2015), pp. 10235-10241. https://doi.org/10.1007/s11356-015-4226-z

[13] Etto, H. Y. Detecção de bactérias do gênero Legionella em amostras de água provenientes de sistemas de ar condicionado. Dissertação de Mestrado. Universidade de São Paulo, São Paulo, Brazil, 2009.

[14] Carvalho, M. T. C.; Cunha, S. O.; Faria, R. A. P. G. Caracterização quali-quantitativa da água da condensadora de aparelhos de ar condicionado. III Congresso Brasileiro de Gestão Ambiental, Goiás, Brazil, 2012.

[15] Al-Farayedhi, A. A.; Ibrahim, N. I.; Gandhidasan, P.: “Condensate as a water source from vapor compression systems in hot and humid regions" Desalination, Vol. 349 (2014), pp. 60-67. http://dx.doi.org/10.1016/j.desal.2014.05.002

[16] Nóbrega, J. M. de S. Água residual de condensadores de ar: perspectiva de substituição à água destilada para uso em laboratórios. Trabalho de Conclusão de Curso. Universidade Federal de Campina Grande, Paraíba, Brazil, 2015.

[17] CLSI (Clinical and Laboratory Standards Institute). Preparation and testing of reagent water in the clinical laboratory. Proposed Guideline - 4- Edition. document C3-p4, 2015.

[18] Libânio, M. Fundamentos de qualidade e tratamento de água. $3^{\text {a }}$ Edição. SP: Editora Átomo, Campinas, Brazil, 2010. 